\title{
KOMPARATÍVNA ANALÝZA UPLATŇOVANIA SPOLOČENSKY ZODPOVEDNÉHO PODNIKANIA VO VYBRANÝCH POŠTOVÝCH PODNIKOCH
}

\author{
Vladimíra Žiačková*
}

Úvod

Pošta ako odvetvie národného hospodárstva patrí do terciárneho sektora, často sa však uvádza aj kvartálny sektor, čo súvisí najmä s rastom významu informácí́. Poštový sektor je jedným z významných činitel'ov upevňovania národnej i politickej jednoty krajiny, prostriedkom rozvoja medzinárodných vzt’ahov, jedným z činitel'ov ekonomického rozvoja, prostriedkom uspokojovania potrieb obyvatel'stva a tiež významným prvkom výrobného procesu.

Tieto charakteristiky v súčasnosti kladú aj na poštové podniky požiadavku na spoločensky zodpovedné podnikanie s ohl'adom na vonkajšie prostredie a všetky zainteresované subjekty. Spoločensky zodpovedný podnik nemá za ciel' len maximalizáciu zisku alebo zvyšovanie hodnoty podniku, ale jeho ciele vychádzajú z potrieb prostredia, v ktorom podniká a zahŕňajú aj sociálne a environmentálne aspekty jeho činnosti.

\section{Poštový sektor a poštový podnik}

Poštový sektor a sektor elektronických komunikácií plnia významné funkcie pre spoločnost', ktoré spočívajú v:

口 informačnom systéme - vytváraním komunikačných ciest umožňujúcich prekonanie priestorových vzdialeností medzi jednotlivými čast'ami štátu a slúžiacich $\mathrm{k}$ ich vzájomného informačnému vyrovnávaniu a zjednocovaniu, čím sa vytvárajú predpoklady priestorovej integrácie štátu;

口 prepravnom systéme štátu - zabezpečovaním prepravy informácií na fyzicky objemných médiách, prepravy predmetov alebo tovaru, prípadne aj hromadnej prepravy osôb;

口 peňažnom systéme - významným podielom na manipulácii s obeživom, a to v rámci platobného styku, obstarávatel'ských činností a bankovníctva;

- sociálnej politike - zdôrazňovaním úrovne a počtu pracovných príležitostí;

口 regionálnej politike - tendenciou k pretváraniu lokalitných, regionálnych štruktúr tak z hl'adiska správy, ako aj z hladiska niektorých účelových funkcií - možno hovorit' o integrácii, ktorej ciel'om je vecná a ekonomická účinnost'. [1]

\footnotetext{
${ }^{*}$ Ing. Vladimíra Žiačková, Žilinská univerzita v Žiline, Fakulta Prevádzky a ekonomiky dopravy a spojov, Katedra spojov, Univerzitná 1, 01026 Žilina, tel. č.: 041/513 3144, e-mail: vladimira.ziackova@fpedas.uniza.sk
} 
Podl’a klasifikácie ekonomických činností SK Nace Rev. 2, ktorá bola vypracovaná na základe európskej klasifikácie NACE Rev. 21 a nahradila odvetvovú klasifikáciu ekonomických činností známu pod skratkou OKEČ, pracovné činnosti v pošte sú zaradené v sekciách H - Doprava a skladovanie, J - Informácie a komunikácia, K - Finančné a poist'ovacie činnosti a $\mathrm{L}$ - Činnosti v oblasti nehnutel'ností.

Poštový podnik podla $§ 5$ zákona č. 507/2001 Z. z. o poštových službách v znení neskorších predpisov je podnik, ktorý poskytuje poštové služby. O poskytovanie poštových služieb ide vtedy, ak obsahom činnosti podnikatel'a je vyberanie alebo dodávanie oznámení a vecí, ktoré sú podl'a $\S 4$ poštovými zásielkami. Poštový podnik môže poskytovat' poštové služby len na základe živnostenského oprávnenia, v rozsahu všeobecného povolenia a za podmienok ustanovených týmto zákonom.

\section{Komparatívna analýza CSR v poštových podnikoch}

Mnohé svetové poštové podniky uplatňujú princípy spoločensky zodpovedného podnikania a sú aktívnymi členmi Iniciatívy UN Global Compact, ktorú zastrešuje Organizácia Spojených národov. V tabul'ke 1 sú uvedené poštové podniky, ktoré sú pridružené k tejto iniciatíve.

Tabul'ka 1.

Poštové podniky participujúce na iniciatíve Global Compact

\begin{tabular}{|l|l|c|}
\hline \multicolumn{1}{|c|}{ Poštový podnik } & Krajina pôsobnosti & $\begin{array}{c}\text { Dátum pričlenenia sa } \\
\text { k iniciatíve }\end{array}$ \\
\hline International Post Corporation & Belgicko & $2008 / 12 / 26$ \\
\hline Post Danmark & Dánsko & $2009 / 01 / 26$ \\
\hline Deutsche Post DHL & Nemecko & $2006 / 07 / 20$ \\
\hline Hungarian Post & Mad'arsko & $2006 / 05 / 04$ \\
\hline Japan Post Group & Japonsko & $2008 / 05 / 01$ \\
\hline Business Post Group & Vel'ká Británia & $2009 / 02 / 17$ \\
\hline Royal Mail Group & Vel'ká Británia & $2005 / 04 / 06$ \\
\hline Austrian Post & Rakúsko & $2007 / 08 / 24$ \\
\hline Groupe La Poste & Francúzsko & $2003 / 03 / 18$ \\
\hline Albanian Post & Albánsko & $2007 / 05 / 24$ \\
\hline Iceland Post & Island & $2009 / 07 / 20$ \\
\hline An Post & Írsko & $2010 / 08 / 04$ \\
\hline
\end{tabular}

Zdroj: vlastné spracovanie

Táto iniciatíva zastrešuje základné princípy definujúce minimálne ekologické a sociálne štandardy. Opiera sa o princípy verejnej zodpovednosti, transparentnosti a otvoreného dialógu v záujme zabezpečenia priestoru pre inováciu.

Pre posúdenie súčasného stavu pri uplatňovaní spoločensky zodpovedného podnikania je riešenie uvedenej problematiky zamerané na najvýznamnejšie aktivity vybraných poštových podnikov.

\footnotetext{
${ }^{1}$ Klasifikácia SK Nace Rev. 2 bola vydaná Nariadením Európskeho parlamentu a Rady č. 1893/2006; je dostupná na: http://www.colnasprava.sk/wps/PA_1_0_9D/OpenFile/f_orgnace2007metodika_07.pdf?docID=SazkKaXVfc317EKrXEahT DDIF4.
} 


\section{Slovensko - Slovenská pošta, a. s.}

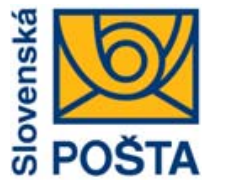

Na slovenskom trhu v súčasnosti pôsobí 23 registrovaných poštových podnikov poskytujúcich poštové služby podl'a zákona č. 507/2001 Z. z. o poštových službách. Čoraz viac sa tu začínajú presadzovat' zahraniční poštoví operátori prostredníctvom svojich zahraničných zastúpení, ako aj slovenské spoločnosti poskytujúce služby distribúcie poštových zásielok. Na základe údajov Štatistického úradu Slovenskej republiky o tržbách za vlastné výkony a za tovar, divízie Poštové služby a služby kuriérov, bol v roku 2009 podiel Slovenskej pošty na trhu poštových služieb približne $72 \%$.

Slovenská pošta, a. s. nepublikuje etické kódexy, príp. správy o spoločensky zodpovednom podnikaní a informácie o dianí v oblasti spoločenskej zodpovednosti je možné zaznamenat' len ojedinele. To však neznamená, že spoločensky zodpovedné aktivity nie sú zaradené do jej činnosti. Už samotná stratégia podniku kladie dôraz na trvalo udržatel'ný rozvoj, na kvalitu poskytovaných služieb, spokojnost' zákazníkov a investorov. Koncepcia rozvoja Slovenskej pošty, a. s. odzrkadl'uje snahu manažmentu o stabilizáciu, konsolidáciu a zabezpečenie trvalého a udržatel'ného rozvoja podniku s naplnením požiadaviek širokej zákazníckej základne pri dodržaní kvality univerzálnej služby stanovenej v poštovej licencii.

Slovenská pošta uplatňuje moderný, efektívny a sociálne zodpovedný štýl riadenia spoločnosti s ciel'om zabezpečovat' jej dlhodobý, udržatel'ný a konkurencieschopný rozvoj. Predstavenstvo podniku schválilo dokument o firemnej kultúre, ktorý vymedzuje pracovné hodnoty, zásady medzil’udských vzt’ahov a etických princípov, či už smerom dovnútra podniku s orientáciou na zamestnancov alebo smerom navonok s orientáciou na zákazníkov. V dokumente Environmentálna politika SP, a. s. deklaruje princípy spoločensky zodpovedného podnikania s ohl'adom na všetky piliere tohto konceptu. Slovenská pošta uplatňuje tieto princípy spoločensky zodpovedného podnikania:

- do všetkých aspektov podnikatel'skej činnosti premieta kritériá a požiadavky na ochranu životného prostredia v snahe zmiernit' nepriaznivé vplyvy všetkých svojich činností na životné prostredie;

- usiluje sa o snahu dosiahnut' rovnováhu ekonomických, environmentálnych a sociálnych ciel'ov a túto zohl'adňuje pri vytváraní hodnôt pre zákazníkov a zamestnancov;

口 V starostlivosti o životné prostredie uplatňuje princíp prevencie vo vzt'ahu k produkcii odpadov a šetreniu energií;

口 o zabezpečovaní ochrany životného prostredia informuje verejnost';

- systém riadenia $v$ environmentálnej oblasti udržuje a zlepšuje prostredníctvom stanovených ciel'ov a plnením programov na ich realizáciu.

Ak by sme hl'adali konkrétne znaky kvalitného riadenia a zodpovednosti voči spoločnosti, mohli by sme uviest' napr. hodnotenie ratingovej agentúry Moody's, ktorá udelila Slovenskej pošte v roku 2006 rating úverového rizika na úrovni Aaa.sk, čo je najvyššia možná úroveň. Odvtedy sa rating Slovenskej pošty nemenil a jeho výhl'ad ratingu je nad'alej stabilný. V roku 2008 spoločnost' získala certifikáty, ktoré potvrdzujú zavedenie a udržiavanie systému manažérstva kvality a systému environmentálneho manažérstva zodpovedajúce požiadavkám normy STN EN ISO 9001:2001 a STN EN ISO 14001:2005. Spoločnost' je taktiež držitel'om prestížnej ceny HR Gold za inovatívny projekt v personalistike. Certifikáty zaväzujú spoločnost' k trvalému zlepšovaniu, s čím súvisí aj neustále skvalitňovanie a zefektívňovanie služieb s ciel'om zvyšovania spokojnosti zákazníkov Slovenskej pošty.

Celosvetová ekonomická kríza zasiahla všetky odvetvia, poštový sektor nevynímajúc. Napriek nepriaznivej finančnej a ekonomickej situácii v spoločnosti sa Slovenská pošta 
pripojila $\mathrm{k}$ iniciatíve vlády SR a $\mathrm{k}$ Memorandu o spolupráci pri riešení vplyvov finančnej a hospodárskej krízy okrem iného aj tým, že v roku 2009 uprednostnila zachovanie pracovných miest pred zvyšovaním priemernej mzdy svojich zamestnancov. Takmer každý poštový podnik vo svete musel realizovat' viaceré opatrenia na zníženie nákladov. Mnohé z týchto opatrení boli razantné a vo vel'kej miere ovplyvnili nielen výšku miezd, ale aj zamestnanost' v podniku. Takéto zásahy sa však Slovenskej pošty nedotkli, čo možno považovat' za najväčší prejav zodpovednosti voči zamestnancom.

Slovenská pošta, a. s. sa popri svojich aktivitách snaží o znižovanie negatívnych vplyvov na životné prostredie. Pri realizácii vnútorných auditov kvality a environmentu sa ukázalo, že bol napĺn̆aný ciel' v udržiavaní trendu neustáleho zlepšovania, skvalitňovania a zefektívňovania poskytovaných služieb $\mathrm{v}$ prospech zákazníkov a $\mathrm{v}$ znižovaní environmentálnych vplyvov podniku na životné prostredie.

Z d'alších aktivít je možné uviest' projekt určený det'om - Vianočná pošta. V roku 2010 Slovenská pošta, a. s. bude organizovat' už 12. ročník tohto projektu. Ďalšou prosociálnou aktivitou je iniciatíva Slovenskej pošty, a. s. na pomoc l'ud'om v štyroch obciach postihnutých povodňami. Pošta umožnila bezplatné zasielanie balíkov do týchto obcí, pričom za desat' dní bolo zaslaných vyše 1500 balíkov, ktorých obsahom bola nevyhnutná pomoc pre povodňami postihnuté obce. [2]

\section{Rakúsko - Österreichische Post AG}

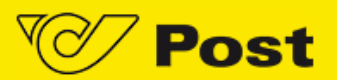

Rakúska pošta (Österreichische Post AG) je jednou z najväčších spoločností v krajine a plne si uvedomuje svoju zodpovednost' nielen voči komunite, v ktorej pôsobí, ale aj voči spoločnosti ako takej. Z tohto dôvodu spoločnost' uznala a definovala aktivity zodpovedného podnikania voči záujmovým skupinám ako súčast' podnikovej stratégie a zároveň ako súčast' všetkých podnikových činností. Rakúska pošta, v rámci spoločensky zodpovedných aktivít, vychádza z princípov UN Global Compact ked'že od roku 2007 je oficiálnym členom tejto dobrovol'nej iniciatívy.

Spoločnost' definuje stakeholderov vo vzt’ahu k spoločensky zodpovednému podnikaniu, ktorými sú:

口 zákazníci - dobré vzt'ahy so zákazníkmi sú z pohl'adu vrcholového manažmentu Rakúskej pošty základom úspechu celej spoločnosti (prioritou je poskytovanie poštových služieb za primerané ceny);

口 akcionári (shareholders) - v ostatných rokoch Rakúska pošta vypláca vysoké dividendy svojim akcionárom, vrátane jej majoritného akcionára ÖIAG (a tým štátu);

- zamestnanci - spoločnost' má viac ako 23000 zamestnancov v Rakúsku a 4000 zamestnancov v zahraničí; vel'kú zodpovednost' pripisuje najmä udržiavaniu pozície v rámci počtu zamestnancov a zabezpečeniu spokojnosti zamestnancov, pričom svoju pozornost' sústred'uje na aktívnu podporu rozvoja zamestnancov;

- obchodni partneri - snahou spoločnosti je vystupovat' ako bezúhonný, spol'ahlivý a predvídatel'ný obchodný partner pre svojich dodávatel'ov a ostatných obchodných partnerov;

- environmentálne skupiny (životné prostredie) - svoju povinnost' chránit' životné prostredie dokazuje neustále prebiehajúcou modernizáciou infraštruktúry, aktivitami súvisiacimi s recykláciou odpadov a programami zameranými na redukciu spotreby vzácnych prírodných zdrojov;

口 miestna komunita - charakteristickými znakmi vzt’ahu medzi Rakúskou poštou a miestnou komunitou sú otvorený dialóg a celonárodná pôsobnost' (poštové služby sú poskytované v odl'ahlých územiach prostredníctvom zmluvných partnerov); 
- spoločnost' - Rakúska pošta je jedným z najväčších národných zamestnávatel'ov a jej poštová siet' poskytuje prístup ku kvalitným poštovým službám pre všetkých obyvatel'ov.

$\mathrm{Na}$ základe určených stakeholderov a zodpovednosti voči nim, Rakúska pošta definovala 4 piliere udržatel'ného rozvoja:

\section{1. pilier: Hospodárenie:}

Iba spoločnost', ktorá expanduje a dlhodobo generuje zisk môže prevziat' dlhodobú zodpovednost' za efekty svojej činnosti a vytvárat' primerané podmienky pre napíňanie sociálnych potrieb. Prioritou Rakúskej pošty v tejto oblasti je zaistit' dlhodobú ziskovost'. Na splnenie tohto prioritného ciel'a spoločnost' prijíma opatrenia na udržanie konkurencieschopnosti a implementuje medzinárodnú stratégiu navrhnutú za účelom dosiahnutia dlhodobého úspechu spoločnosti.

\section{2. pilier: Spoločnost':}

Rakúska pošta ako poskytovatel' univerzálnej služby je v tomto zmysle povinná dodržiavat' zásady spoločensky zodpovedného podnikania, a to tým, že vynakladá značné finančné prostriedky na údržbu a ochranu komunikačnej infraštruktúry krajiny. Záujmom spoločnosti je najmä zabezpečenie spol'ahlivosti a kvality poštových služieb poskytovaných obyvatel'stvu. Rovnako reaguje na výzvy podmienené vzrastajúcou konkurenciu prostredníctvom neustálych inovácií prospešných pre celú spoločnost'.

\section{3. pilier: Zamestnanci:}

Predpokladmi pre získanie a udržanie si kvalitných zamestnancov je zabezpečenie vhodného, neškodlivého a bezpečného pracovného prostredia. Značná čast' zamestnancov sa musí priebežne prispôsobovat' meniacim sa podmienkam, ktoré sú spôsobené optimalizáciou a inováciou procesov. Preto je potrebné neustále organizovat'vzdelávanie zamestnancov, ktoré pošta zabezpečuje vo svojom Rozvojovom centre. V rámci tohto piliera spoločnost' dbá aj na sociálne aspekty, napr. vyváženost' osobného a pracovného života, rovnost' v odmeňovaní, zdravie a bezpečnost' zamestnancov a pod.

\section{4. pilier: Životné prostredie:}

Efektívne využívanie prírodných zdrojov je tiež dôležitou prioritou Rakúskej pošty, čo preukázala snahou o znižovanie spotreby zdrojov, hospodárnost'ou v preprave, využívaním ekologických dopravných prostriedkov, prípadne aktívnou participáciou na environmentálnych projektoch (napr. Program PostEurop - Asociácie európskych verejných poštových operátorov pre znižovanie skleníkových plynov spôsobujúcich skleníkový efekt). [3]

\section{Vel'ká Británia - Royal Mail Group}

V prípade Britskej pošty je na prvý pohl'ad zrejmé, že téme zodpovednosti voči spoločnosti sa venuje už dlhší čas. Ku iniciatíve Global Compact sa Royal Mail pripojila už v roku 2005 a od tohto roku prešli jej aktivity v oblasti zodpovedného podnikania rozsiahlym vývojom. Zaujímavá je najmä webová doména venovaná práve spoločenskej zodpovednosti, na ktorej sú uvedené podrobné informácie o tom, $\mathrm{v}$ akých oblastiach spoločenskej zodpovednosti sa spoločnost' angažuje, kto je zodpovedný za jej uplatňovanie, ako spoločnost' riadi aktivity v tejto oblasti, aké ocenenia získala a pod.

Na prelome rokov 2008 a 2009 Britská královská pošta vydala v poradí siedmu Správu o spoločensky zodpovednom podnikaní, ktorá obsahuje podrobný popis aktivít realizovaných v ekonomickej, pracovnej, komunitnej a environmentálnej oblasti spolu $\mathrm{s}$ rozpočtom nákladov vynaložených na tieto účely. Spoločnost' vyzdvihuje 5 popredných 
aktivit, ktorými demonštruje svoj záujem podnikat' zodpovedne a vyvíjat' podporné aktivity voči zamestnancom, zákazníkom a dodávatel'om:

- uplatňovat' rovnoprávnost' a spravodlivost' na každom pracovisku;

- zabezpečit' vysokú úroveň bezpečnosti na pracovisku;

- poskytovat' podporu k zabezpečeniu zdravia všetkých zamestnancov;

- mat' pozitívny sociálny vplyv na zamestnancov, komunity, zákazníkov a dodávatel'ov;

- pomáhat' zákazníkom (podnikatel'ských subjektom) podnikat' ekologicky udržatel’ným a konkurencieschopným spôsobom. [4]

\section{Nemecko - Deutsche Post DHL}

Deutsche Post 1 Nemecká Deutsche Post, ktorá je divíziou spoločnosti Deutsche Post DHL realizuje v oblasti spoločenskej zodpovednosti množstvo aktivít doma aj v zahraničí. Každoročne publikuje správy o spoločenskej zodpovednosti pod hlavičkou „Living Responsibility“, získala hodnotenie FTSE 4 Good Index2, taktiež získala hodnotenie indexom „The ASPI Eurozone“, ktorý je európskym indexom referenčných spoločností a investorov, ktorí sa zaviazali podnikat' s prihliadnutím na trvalo udržatel'ný rozvoj a spoločenskú zodpovednost'. V oblasti environmentu získala hodnotenie indexom „FTSE KLD Global Climate 100 Index“, ktorý podporuje investície do 100 verejných spoločností, ktoré preukazujú najväčší potenciál pre znižovanie klimatických zmien. V januári 2009 vyústili jej aktivity pripojením sa k organizácii World Business Council for Sustainable Development.

Aktuálna správa, publikovaná v apríli 2010, zahŕňa informácie o spoločensky zodpovednom podnikaní všetkých divízií a dcérskych spoločností vo viac ako 220 krajinách a informácie o financovaní týchto aktivít. Táto správa bola vytvorená na základe Global Reporting Initiative (GRI) tretej generácie známej ako „G3“ a to v rámci sektora logistiky a dopravy. Stratégia spoločnosti v oblasti spoločensky zodpovedného podnikania dokonale kopíruje PDCA cyklus, ked’že nie je len jednoduchým zhrnutím aktivít, ale obsahuje aj spätnú väzbu a plán aktivít spolu s ohraničením časového horizontu ich realizácie.

Prístup Deutche Post ku spoločenskej zodpovednosti vyplýva zo stratégie spoločnosti s názvom „Stratégia 2015“, ktorá podporuje záväzok k trvalo udržatel'nému rozvoju, $\mathrm{k}$ dosiahnutiu dlhodobých ciel'ov s ohl'adom na ochranu životného prostredia, k podpore komunity a zamestnancov. Stratégia spoločensky zodpovedného podnikania podniku je postavená na troch základných programoch - „GoGreen, GoHelp a GoTeach“, ktoré zodpovedajú zameraniu prospešných aktivít $\mathrm{v}$ oblasti životného prostredia, pomoci obyvatel'stvu v prípade prírodných katastrof a v oblasti vzdelávania zamestnancov. [5]

\section{Švajčiarsko - Swiss Post}

SWISS POST П $\begin{aligned} & \text { Svajčiarska pošta sa v rámci svojej stratégie snaží o vyrovnanú } \\ & \text { ekonomickú, sociálnu a environmentálnu zodpovednost'. Podnik je }\end{aligned}$ aktívny vo všetkých oblastiach spoločenskej zodpovednosti. Je držitel'om certifikátu ISO 14001:2004, ktorý potvrdzuje zavedenie a udržiavanie systému environmentálneho manažérstva. Počas svojho pôsobenia sa zaviazal k mnohým iniciatívam („Pozitívne so zdravotným postihnutím“, „Investovanie do l'udi““ a pod.) a participuje na mnohých projektoch určených na podporu komunity.

\footnotetext{
2 Tento burzový index meria výkonnost' spoločností, ktoré spíňajú globálne uznávané štandardy pre spoločensky zodpovedné podniky.
} 
V správe o udržatel'nom rozvoji Rakúska pošta identifikuje svoj klúčový záujem v oblasti zodpovedného podnikania takto: „Vd'aka vel'kému podielu zainteresovanosti na klientskych operáciách po celej krajine, kl'účovým aspektom zodpovednosti organizácie je zodpovedný prístup $k$ všetkým našim činnostiam a $k$ podpore a rozvijaniu spoločensky zodpovedných cielov našich klientov, z ktorých mnohi dosahujú v rámci zodpovedného podnikania vysoké hodnoty CR Indexu. “"

Švajčiarska pošta presadzuje princíp rovných príležitostí v zamestnaní a stavia sa proti všetkým formám nezákonnej alebo neoprávnenej diskriminácie. Rovnako si je vedomá svojej zodpovednosti voči životnému prostrediu, preto sa usiluje o neustále znižovanie environmentálnych rizík. Zodpovednost' voči komunite definuje v rámci svojej stratégie, pričom sa zameriava na jej ekonomické a sociálne potreby.

Ako súčast' svojej politiky, pošta sleduje štyri hlavné strategické smery:

- znižovat' environmentálne riziká,

- trvalo udržatel'ne nakladat's prostriedkami,

- spoločensky zodpovedné podnikanie využit' ako trhovú príležitost',

- stat' sa viac atraktívnym zamestnávatel’om. [6]

\section{Austrália - Australia Post}



Spoločensky zodpovedné podnikanie v spojení s Austrálskou poštou je relatívne novým pojmom, ked’že stratégiu zodpovedného podnikania začala profilovat' v roku 2008. Jej víziou je "prispiet' každý deň $\mathrm{k}$ udržatel'nému zajtrajšku". Základom koncepcie spoločensky zodpovedného podnikania je sedem strategických ciel'ov:

- minimalizovat' negatívny dopad na životné prostredie;

- investovat' do komunít, s ktorými pri vykonávaní podnikatel'skej činnosti prichádza do kontaktu;

- poskytovat' hodnotné služby s ohl'adom na spoločenskú zodpovednost';

- integrovat' spoločensky zodpovedné aktivity do dodávatel'ského ret’azca;

- svojou činnost'ou prispievat' k snahe o trvalo udržatel'ný rozvoj;

- porozumiet' potrebám a očakávaniam stakeholderov;

- zaistit' efektívne riadenie a podávanie správ v oblasti spoločensky zodpovedného podnikania.

Prvá Správa o spoločensky zodpovednom podnikaní bola publikovaná v roku 2009 a na základe Global Reporting Initiative boli určené hlavné oblasti záujmu Austrálskej pošty, a to prístup k poštovým službám, ekonomická výkonnost', zamestnanost', úspora energie, ochrana osobných údajov, emisie, odpadové vody, súlad s právnymi predpismi, priame ekonomické vplyvy, rozmanitost' na pracovisku a rovnost' príležitostí, zloženie vozového parku. [7]

\section{Japonsko - Japan Post Group}

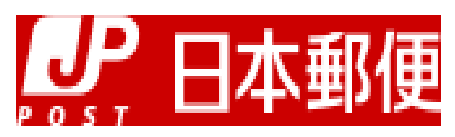

Holding Japan Post Group má štyri divízie - „Japan Post Network, Japan Post Service, Japan Post Bank a Japan Post Insurance“. Podnik, ktorý zastrešuje všetky funkčné oblasti pošty -

\footnotetext{
${ }^{3}$ Corporate Responsibility (CR) Index je index zverejnený organizáciou Business in the Community a predstavuje benchmark v oblasti zodpovedného podnikania. Tento index obsahuje zároveň metodiku implementovania CSR v podniku, pomáha podnikov integrovat' CSR do podnikových operácií pomocou systematického riadenia, merania a reportovania vplyvov podnikov na spoločnost' a prostredie.
} 
poskytovanie služieb, poštovú siet', poštovú banku a poist'ovňu, sa vyznačuje dobre prepracovanou politikou zodpovedného podnikania medzi analyzovanými svetovými poštovými operátormi.

V Japonskej pošte je spoločenská zodpovednost' prostriedkom pre podnikanie v súlade $\mathrm{s}$ vysokými štandardmi, ktoré si podnik stanovil. Dodržiavanie týchto štandardov prispieva $\mathrm{k}$ dodržiavaniu filozofie podniku a $\mathrm{k}$ zabezpečeniu trvalo udržatel'ného rozvoja. $\mathrm{V}$ súlade $\mathrm{s}$ týmto pohl'adom na zodpovedné podnikanie, bolo definovaných sedem oblastí záujmu, z ktorých tri sú prioritné.

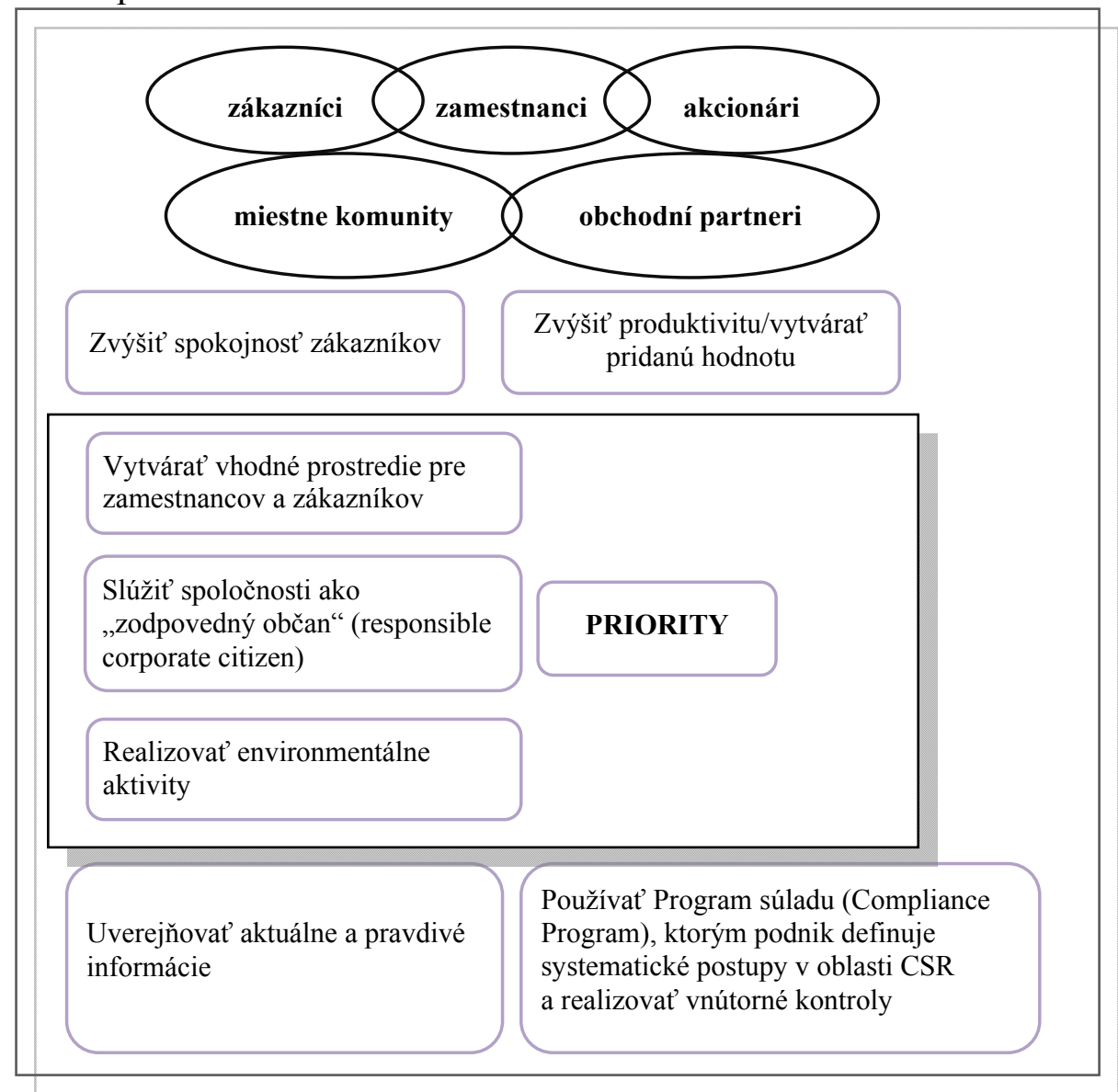

Obrázok 1. Oblasti spoločensky zodpovedných aktivít Japonskej pošty Zdroj: Výročná správa Japan Post Group 2009, s. 72.

Aktivity z každej znázornenej oblasti záujmu sú podrobne popísané v Správe o spoločenskej zodpovednosti. [8]

\section{Kanada - Canada Post}

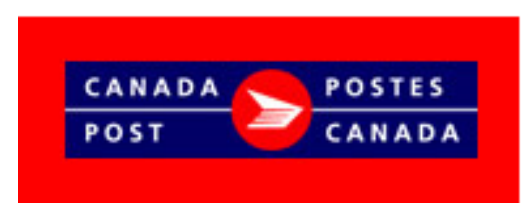

Kanadská pošta vkladá spoločenskú zodpovednost' do všetkých aspektov podnikania - investuje do zamestnancov, podnikových procesov, infraštruktúry, komunity a životného prostredia.

Centrálnym bodom záujmu podniku sú jeho stakeholderi, čo dokazuje aj výsledok nezávislého prieskumu vybraných 1115 spoločností na celom svete. Kanadská pošta sa stala jednotkou $\mathrm{v}$ tomto prieskume práve $\mathrm{z}$ dôvodu výnimočnej zainteresovanosti na zodpovednosti voči záujmovým skupinám. [9] V tabul'ke 2 sú uvedené základné oblasti spoločensky zodpovedného podnikania Kanadskej pošty: 
Tabul'ka 2

Spoločensky zodpovedné aktivity Kanadskej pošty

\begin{tabular}{|c|c|c|c|c|}
\hline & Ekonomická oblast' & Environmentálna oblast' & \multicolumn{2}{|c|}{ Sociálna oblast' } \\
\hline & Finančná udržatel'nost' & Životné prostredie & Zamestnanci & Komunity \\
\hline 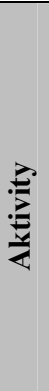 & $\begin{array}{l}\text { - bezpečnost' } \\
\text { a súkromie, } \\
\text { - riadenie hodnoty } \\
\text { zákazníka } \\
\text { - spol'ahlivost' } \\
\text { doručovania } \\
\text { - postupy verejného } \\
\text { obstarávania } \\
\text { - povinnost' } \\
\text { univerzálnej služby }\end{array}$ & $\begin{array}{l}\text { - emisia skleníkových } \\
\text { plynov } \\
\text { - zelené budovy } \\
\text { - environmentálna } \\
\text { udržatel'nost' } \\
\text { - hospodárenie } \\
\text { s odpadmi } \\
\text { - „zelené produkty } \\
\text { a služby“ }\end{array}$ & $\begin{array}{l}\text { - zdravie } \\
\text { a bezpečnost' } \\
\text { - } \text { angažovanost' } \\
\text { zamestnancov } \\
\text { - } \text { spravodlivost' } \\
\text { - } \text { rôznorodost' na } \\
\text { pracovisku } \\
\text { - vzdelávanie } \\
\text { a rozvoj }\end{array}$ & $\begin{array}{l}\text { - duševné zdravie, } \\
\text { - gramotnost' } \\
\text { - } \text { komunitné programy } \\
\text { - } \text { sponzorstvo a dary }\end{array}$ \\
\hline
\end{tabular}

Zdroj: Social Responsibility Report 2009 Canada Post, s. 13.

Mnohé d’alšie európske poštové podniky sú podobne aktívne v oblasti spoločenskej zodpovednosti.

\section{Záver}

Z uskutočnenej komparatívnej analýzy a z preštudovaných podkladov z jednotlivých poštových podnikov môžeme vyslovit' záver, že prístup poštových podnikov je v prevažnej miere systémový. Podniky majú určené v organizačných štruktúrach útvary, ktoré pokrývajú záber tejto problematiky. Podniky, ktoré zverejňujú správy o spoločensky zodpovednom podnikaní majú definovanú stratégiu a parciálne ciele, od ktorých sa odvíjajú d'alšie aktivity. Vel'ká čast' poštových podnikov vytvára tieto správy na základe iniciatívy UN Global Compact - G2, príp. G3.

Poštové podniky, ktoré uplatňujú spoločensky zodpovedné podnikanie dlhšie ako 5 rokov majú definovaných stakeholderov v každej rovine konceptu spoločensky zodpovedného podnikania. Podniky, ktoré takéto dlhoročné skúsenosti nemajú, viažu svoje aktivity v rámci zodpovedného podnikania najmä na zákazníkov, zamestnancov a miestnu komunitu. Príkladom dobrej praxe je Rakúska pošta, ktorá na základe určených stakeholderov definuje piliere svojho udržatel'ného rozvoja.

Oblast' reportovania zodpovedného podnikania u menších poštových operátorov je v súčasnosti v počiatkoch. Vel'ké poštové podniky vytvárajú správy o spoločenskej zodpovednosti niekol'ko rokov (v prevažnej miere približne od roku 2003), pričom postupne využívajú vyššie štandardy reportovania. Prevažujú správy zamerané na trvalo udržatel'ný rozvoj, čo vyplýva z charakteru poštového sektora. V zásade platí skutočnost', že prvky spoločensky zodpovedného podnikania nájdeme takmer u každého poštového podniku vo výročných správach, kde sú uvedené aj finančné zdroje vynaložené na jednotlivé aktivity.

Poštové podniky, ktorých politika je celoplošná (v ekonomickej, sociálnej a environmentálnej oblasti) sú na najvyššej úrovni implementácie spoločensky zodpovedného podnikania. Takúto úroveň dosahuje napr. Rakúska pošta, Deutsche Post DHL, Kanadská, Dánska, Nórska a Švédska pošta. Všetky pošty, ktoré participujú na iniciatíve UN Global Compact sa vyznačujú komplexne zameranou politikou v danej oblasti. Ostatné poštové podniky sa zameriavajú na sociálnu oblast' a na oblast' ochrany životného prostredia. 


\section{Literatúra}

[1] ČOREJOVÁ, T., et al.: Ekonomika sietí. 2. vyd., Žilina: EDIS, 2010, 322 s. ISBN 97880-554-0155-3.

[2] Výročné správy Slovenskej pošty, a. s. za roky 2006 - 2009.

[3] Austrian Post AG - Sustainability Report, 2009.

[4] Royal Mail Group Corporate Social Responsibility Report, 2008/09.

[5] Deutsche Post DHL - Corporate Responsibility Report, 2009/10.

[6] Swiss Post - Sustainability Report, 2009.

[7] Australia Post Corporate Responsibility Report, 2008/09.

[8] JAPAN POST GROUP, Annual Report, 2008, 2009.

[9] Social Responsibility Report - Canada Post, 2007- 2009.

[10] La Poste - 2008 sustainable development overview.

[11] Magyar Posta - SUSTAINABILITY REPORT 2008.

[12] United States Postal Service - Sustainability Report, 2009.

[13] Posten Sweden - Posten's Sustainability Report, 2008.

[14] Posten Norden - Sustainability Report, 2009.

[15] Poste Italiane - Social report, 2007, 2008.

[16] THE POST DANMARK GROUP - Sustainability Report, 2008. 